\title{
Research on Innovative Mode of Employment Guidance Service and Entrepreneurship Education for College Students with Financial Difficulties
}

\author{
Chengcheng $\mathrm{Fu}^{*}$ \\ Xi' an Polytechnic University, Xi' an 710048, Shaanxi, China. \\ E-mail: $947650351 @ q q . c o m$
}

\begin{abstract}
Colleges and universities provide students, who have financial difficulties, with employment guidance service and entrepreneurship education. One of the critical problems is to effectively improve the management effectiveness of employment service and entrepreneurship education for these kinds of students. The management of this service and education should be constantly innovated. Based on the practical situation and the current Internet technologies, a new management mode and its details are put forward in this article, and the author seeks to provide reference to who are involved.
\end{abstract}

Keywords: Impoverished College Students; Employment and Entrepreneurship; Education Management; Innovative Mode

\section{Introduction}

Li Keqiang, the Premier of China, pointed out in his speech in 2014 that it is necessary to get ready for mass entrepreneurship, and embrace a new situation of innovation for all, which is just in line with the talent training in higher education. Nowadays, in response to the call of the state, colleges and universities should combine the concept of entrepreneurship with the current teaching work, based on national policies and the development of the times. Due to the various economic backgrounds of students, colleges and universities should study remain issues and find a way out, specially aiming at the employment and entrepreneurship education for students with financial problems.

\section{The importance of upgrading the management of employment and entrepreneurship education for poor college students}

\subsection{An important element of higher education innovation}

With the continuous upgrading and reform of higher education, its educational goal has been changed for good. Universities and colleges are necessary to strengthen the innovative consciousness and practical ability of students, cultivate the employment innovation ability of poor college students, and improve the existing management scheme. Under such background, improving the entrepreneurial ability of poor college students has more critical meaning for the development of employment innovation education in colleges and universities. Schools can better teach students individually. Besides, educational concepts can be better understood, so that students' employment innovation ability can be cultivated in schools. Colleges and universities should also constantly update the management mode of employment innovation education for poor college students, deepen the current teaching reform and accelerate relevant teaching.

Copyright (C) 2020 Chengcheng Fu

doi: 10.18282/le.v9i7.1527

This is an open-access article distributed under the terms of the Creative Commons Attribution Non-Commercial License

(http://creativecommons.org/licenses/by-nc/4.0/), which permits unrestricted non-commercial use, distribution, and reproduction in any medium, provided the original work is properly cited. 


\subsection{An important embodiment of optimizing the level of employment and entrepreneurship in higher education}

Nowadays, colleges and universities are optimizing their employment service and entrepreneurship education, aiming to help poor students improve their abilities. It can not only provide project docking services, policy explanation and related financial support for poor students, but also efficiently enhance the overall employment and entrepreneurship effect. From the long-term perspective, it is the need of college's development and is one of the methods of educational innovation. Colleges and universities can make full use of industry experts or entrepreneurial tutors of alumni units to strengthen the employment.

\subsection{The realistic need for college students with financial difficulties to out of the woods}

From the perspective of development, the main approaches to help college students with financial difficulties get out of woods is to let them have relevant practical abilities and awareness of employment innovation. Under the new era of mass entrepreneurship and innovation, instead of staying on economic assistance, the attention to the cultivation of college students' ability should also be paid to, and the role of funding and educating can't be separated. To help poor students cultivate the ability, employment and entrepreneurship should be consistent with the educational goals, and to fully realize life value of poor college students. Besides, colleges and universities should pay attention to the research of entrepreneurship, set up special funds, provide support for poor students' employment service and entrepreneurship education, and help students improve their abilities. Schools should also help poor college students improve their comprehensive abilities of employment and entrepreneurship, as well as the corresponding practical ability, in order to provide better service of employment and entrepreneurship education for poor college students.

\subsection{An effective way to serve local economic development}

China's economy is currently in the stage of economic transformation. New strength and power need to add to local economic construction and development. The employment innovation education mode for college students should be based on the training of applied talented persons to serve local economic construction and development. Its activities need to be of strong practical significance. Therefore, it is necessary to educate combining local economic development with innovative education to provide development space for poor college students. This service and education provide resources for poor college students who may be employed in local and grass-roots units and become the pillar force in the development of local economy. Colleges and universities should actively practice the innovation of talent training, pay attention to the cultivation and development of poor college students' awareness of employment and entrepreneurship, optimize the comprehensive quality of poor college students, and realize the innovative training of their talents, and promote the local development.

\section{Challenges faced by college students with financial difficulties in employment services and entrepreneurship education}

\subsection{To-be-optimized management system of employment education}

For the current situation, there is still space for innovation in the employment education of poor college students in most universities. Their employment and entrepreneurship management is still carried out in the traditional way. Their systems aren't systematically set up by various operating, ignore the systematic management and unified management of students, and fail to classify their introductory training, content teaching, practice accumulation and hands-on training in teaching. As a result, poor college students still have no systematic operation guide. And there are no timely and effective ways to remedy the problems and difficulties encountered in entrepreneurship ${ }^{[1]}$.

\subsection{To-be-improved practice platform for poor college students' employment and entrepreneurship education}

In the management of employment service and entrepreneurship education, the number of practical platforms is far less than the actual needs. First of all, the number of platforms is far from meeting the actual needs. Some colleges and universities have set up employment and entrepreneurship incubation bases, entrepreneurship parks and other related practical programs. The limitation is that these programs can only be used for teaching, because the practical platforms 
are not linked and integrated with social resources, resulting in limited improvement of ability of poor students.

\subsection{Insufficient resources of employment and entrepreneurship for poor college students}

In the Internet age, the content of employment and entrepreneurship management in higher education should also be optimized. The content should be combined with the relevant experience and the Internet entrepreneurship. Teachers should be good at excavating teaching and learning materials. Colleges and universities should pay attention to the cultivation of this content and enrich the educational resources, so that students can have a clearer understanding of relevant content of employment and entrepreneurship.

\section{Exploration of innovative mode of employment guidance service and entrepreneurship education for college students with financial difficulties}

\subsection{To build a new mode of education management}

In the Internet age, management of employment and entrepreneurship education should also combine the Internet and high-quality resources. In such case, information technology can play its own role and help teachers better solve the problems faced by poor college students, promote the innovation of education management and improve student's practical abilities. For the curriculum setting, attention to its curriculum innovation should be paid to. In order to provide students with high-quality employment and entrepreneurship teaching content, to optimize teaching mode, and to effectively help them get out of difficulties as soon as possible, colleges and universities have made some reforms in teaching methods. These methods aim at the guiding strategy of employment and entrepreneurship, combine with various teaching methods, such as distance education, multimedia teaching, live broadcast, etc., enriching the teaching platform and teaching resources ${ }^{[2]}$.

\subsection{Application of new mode}

The employment and entrepreneurship courses should be more scientific, in which the elective courses and compulsory courses should be set as a three-level system. Moreover, the practical courses and theoretical courses should be combined to realize the comprehensive application of knowledge. Different system courses have different teaching objectives. Firstly, the first level is the curriculum content with simultaneous theory, which mainly aims at helping students understand the employment and entrepreneurship contents and develop pioneering and enterprising skills. Secondly, the secondary curriculum should be combined with its practical ability, mainly to cultivate student's willpower, social skills and vocational skills, and to help students develop their professional ability.

\subsection{Provide more platforms for the practices on campus}

Nowadays, it is necessary for colleges and universities to provide more practicing opportunities on campus. Entrepreneurship parks and business incubation bases can use live broadcast and multimedia and other auxiliary teaching techniques to create a realistic foundation. Secondly, colleges and universities can invest in equipment and facilities, so that students have the opportunity to practice and lay a foundation for school-enterprise cooperation. Both of these methods are conductive to constantly optimize the content of employment and entrepreneurship education for poor college students, and provide more paths for employment and entrepreneurship for poor college students.

\subsection{Create employment-centered and entrepreneurship-centered atmosphere in colleges and universities}

In the management of employment and entrepreneurship education for poor college students, it is necessary to establish scientific values for poor college students, strengthen their socialist core values, cultivate their spirit of employment and entrepreneurship, guide students to establish the spirit of teamwork and continuous exploration, and explore the ability of employment and entrepreneurship with practical application basis. Universities actively hold their entrepreneurial activities, so that poor college students can actively participate in them ${ }^{[3]}$.

\subsection{Build a local entrepreneurial practice platform}

Local colleges and universities should take full account of the combination of natural resources, the advantage of regional resources to better integrate social resources, and develop diversified practical modes, such as campus local 
cooperation projects and school-enterprise alliance, high-quality entrepreneurial practice bases. It is also necessary to enhance school-enterprise cooperation projects, and create local government entrepreneurial demonstration parks. Colleges and universities should also actively carry out entrepreneurial innovation activities to provide poor students with funds, equipment and other services to make them realize their value and life goals through own efforts.

\section{Conclusion}

In summary, it is of great significance to help enhance student's abilities in employment and innovation, especially critical to those with financial difficulties. Firstly, it helps poor college students solve the problem of employment or entrepreneurship. Secondly, it effects the cultivation of applied talented persons and the innovation of teaching mode in higher education. Moreover, it is also a matter of social stability. To provide students the basic employment guidance service and entrepreneurship education is conductive to improve their social competitiveness, strengthen their abilities in employment and entrepreneurship, and promote the harmonious development of colleges and universities.

\section{References}

1. Zheng Y, Cao H. Strengthening the cultivation of innovative entrepreneurship ability of poor college students (in Chinese). Journal of Hubei University of Economics (Humanities and Social Sciences) 2012; (5): 162-163

2. Zhu Y, Zhu J. Explorations on poor college students' starting businesses with the view of development. Journal of Shanxi Youth Vocational College 2016; (3): 36-38.

3. Xia G, Zhou Y, Liu W. Research on the ways of innovation and entrepreneurship education for local college students (in Chinese). Journal of Tonghua Normal University 2017; (2): 91-93 